\title{
PERGESERAN MAKNA ASOSIATIF PADA LIRIK LAGU IWAN FALS DI ALBUM MUSIKAL SATU TAHUN 2015
}

\author{
Iin Ratnasari ${ }^{1}$, Retnowaty ${ }^{2}$, Kiftian Hady Prasetya ${ }^{3}$ \\ Universitas Balikpapan $^{1}$, Universitas Balikpapan ${ }^{2}$, Universitas Balikpapan ${ }^{3}$ \\ Pos-el: iinratnasari8@gmail.com¹, retnowaty@uniba-bpn.ac.id², kiftian@uniba-bpn.ac.id ${ }^{3}$
}

\begin{abstract}
ABSTRAK
Pembahasan yang diangkat oleh peneliti adalah tentang kajian semantik yakni jenisjenis makna. Akan tetapi peneliti hanya memfokuskan pada jenis makna asosiatif dengan rumusan masalah yakni mengenai jenis makna asosiatif yang meliputi makna konotatif, makna stilistik, makna afektif, makna reflektif dan makna kolokatif. Peneliti memilih lirik lagu Iwan Fals album musikal "Satu" tahun 2015 sebagai objek penelitian karena dalam objek tersebut banyak mengandung pembahasan mengenai rumusan masalah tersebut. Jenis metode yang digunakan dalam penelitian ini adalah metode penelitian kualitatif yang bersifat mendeskripsikan data, untuk mempermudah dalam pengumpulan data mengenai makna asosiatif yang terdapat pada lirik lagu Iwan Fals album musikal "Satu" tahun 2015. Peneliti menggunakan kartu data kemudian peneliti menguraikan di pembahasan hasil penelitian. Hasil penelitian yang berjudul Pergeseran Makna Asosiatif Pada Lirik Lagu Iwan Fals Di Album Musikal "Satu" Tahun 2015. Peneliti menemukan jenis - jenis makna asosiatif yaitu makna konotatif makna yang mempunyai nilai rasa, ditemukan sebanyak 14 data. Makna stilistik makna yang berhubungan dengan perbedaan sosial, ditemukan sebanyak 4 data. Makna afektif makna yang berhubungan dengan perasaan pendengar, ditemukan sebanyak 5 data. Makna reflektif makna yang menimbulkan makna lain, ditemukan sebanyak 6 data. Makna kolokatif merupakan makna yang berada pada kolokasi yang sama, ditemukan sebanyak 4 data.
\end{abstract}

Kata Kunci: Makna Asosiatif, Lirik Lagu, Iwan Fals.

\begin{abstract}
The discussion raised by researchers is about semantic studies namely types - types of meaning. However, researchers only focus on the type of associative meaning with the formulation of the problem that is about the type of associative meaning which includes connotative meaning, stylistic meaning, affective meaning, reflective meaning and collocative meaning. Researchers chose the song lyrics of Iwan Fals 'One' 2015 album as an object of research because in the object there were many discussions about the formulation of the problem. The type of method used in this study is a qualitative research method that describes the data, to facilitate data collection regarding associative meanings contained in the song lyrics of Iwan Fals musical album "One" in 2015. Researchers used data cards then the researchers described the results of the study. The results of the study, entitled Shifting Associative Meanings in the Song Lyrics of Iwan Fals in the "One" Musical Album of 2015. Researchers found types of associative meanings that are connotative meanings of meaning that have sense values, found as many as 14 data. The meaning of stylistic meaning related to social differences found as many as 4 data. The affective meaning of meaning that is related to the listener's feelings is found as many as 5 data. The meaning of reflective meaning that gives rise to other meanings is found as many as 6 data. Collocative meaning is a meaning that is in the same collocation, found as many as 4 data.
\end{abstract}

Keywords: Associative Meaning, Lyrics, Iwan Fals. 


\section{PENDAHULUAN}

Bahasa merupakan alat komunikasi yang sangat penting bagi setiap manusia. Kehidupan manusia tidak bisa dilepaskan dari bahasa karena manusia dan bahasa saling terikat. Bahasa memiliki peran penting dalam aktivitas kehidupan manusia yang tidak pernah terlepas dari aktivitas dan sistem kerja manusia selama manusia tersebut masih tergolong sebagai makhluk yang berbudaya dan bermasyarakat. Bahasa yang digunakan sebagai alat komunikasi dalam kehidupan sehari-hari sangat bervariasi, baik dilihat dari fungsi maupun bentuknya. Setiap aktivitas yang dilakukan antar manusia, tidak ada satupun yang tidak disertai dengan kegiatan berbahasa. Dalam kegiatan berkomunikasi melibatkan orang lain tentunya sangat sulit terpisahkan dengan bahasa sebagai alat komunikasi untuk menyampaikan maksud dan tujuan antar pengguna bahasa itu sendiri.

Secara sederhana, bahasa dapat diartikan sebagai alat komunikasi yang dapat digunakan oleh seseorang atau kelompok manusia dalam menyampaikan gagasan pemikiran ataupun maksud serta perasaannya kepada orang lain dengan tujuan tercapainya sebuah jalinan komunikasi antara penutur dan mitra tutur. Pada perkembangannya, bahasa yang digunakan dalam berkomunikasi memiliki banyak ragam dan makna tertentu diantaranya adalah penggunaan bahasa yang mempunyai satuan-satuan makna asosiatif yang mempunyai komponen makna yaitu makna konotatif, makna stilistik, makna afektif, makna reflektif, makna kolokatif. Bahasa dapat dipahami oleh manusia dalam berkomunikasi sebab bahasa mempunyai makna yang sangat luas. Oleh karena itu, mempelajari bahasa juga termasuk mempelajari makna-makna yang sudah disepakati bersama oleh pengguna bahasa. Selain itu, kedudukan bahasa sebagai alat komunikasi memiliki fungsi yang sangat penting dalam menyampaikan pesan atau informasi yang disampaikan melalui bahasa tersebut. Setiap pesan atau informasi memiliki makna yang berbeda-beda bahkan dapat berubah maknanya.

Makna dapat berubah sesuai dengan sifat makna yang dinamis atau berkembang seiring dengan penggunaannya dalam masyarakat pemakai bahasa. Perkembangan masyarakat bahasa ini menghasilkan berbagai perubahan makna dengan berbagai kategori, salah satunya yaitu makna asosiatif. Menurut Leech (Chaer, 2009, p. 72) makna asosiatif yaitu makna yang dimiliki sebuah kata berkenaan dengan adanya hubungan kata itu dengan keadaan di luar bahasa. Makna asosiatif sering dijumpai di berbagai bidang termasuk dalam bidang musik hiburan yaitu pada alunan lagu yang diciptakan oleh para musisi tanah air.

Seiring perkembangan musik itu sendiri juga tidak sedikit musisi yang bermunculan dan mahir menciptakan lagu-lagu yang indah dan mampu meraih banyak prestasi. Namun terkadang kesuksesan membuat seseorang lupa dengan kesopanan dan aturan yang berlaku sehingga mereka sesuka hati menciptakan lagu dengan lirik-lirik yang tidak sopan dan mengandung unsur nesgatif. Meskipun seni tidak membatasi kreativitas seseorang. Akan tetapi, Iwan Fals yang bernama lahir Virgiawan Listanto yang pernah mengalami permasalahan dan beberapa kali berurusan dengan aparat pemerintah karena pada lirik lagu yang berjudul Demokrasi Nasi dianggap tidak sopan dan dapat memancing kerusuhan terhadap pemerintah, sehingga pada masa orde baru lagu tersebut dikatagorikan terlalu keras dan tidak layak untuk di publikasikan. Berikut lirik lagu tersebut:

Anak seorang menteri

Membuat onar lagi 


\section{Menembak sampai mati}

Kok nggak ada sangsi?

Lirik lagu di atas merupakan contoh lirik lagu yang mengandung unsur negatif. Namun Iwan Fals berani menciptakan lirik lagu yang mengungkapkan secara langsung mengenai pemerintahan yang berada ditanah air. Hal tersebut ditemukan pada saat peneliti mendengarkan lagu-lagu Iwan Fals di album musikal "Satu" tahun 2015 tersebut yang menarik mengangkat tema kritikan untuk para penolak, percintaan dan kalangan pejabat politik pemerintahan. Selain itu, setiap lagu-lagu tersebut mengandung makna tersirat di dalamnya yang berupa makna asosiatif.

Dalam hal ini, makna asosiatif yang terdapat pada lirik lagu Iwan Fals di album musikal "Satu" tahun 2015 tersebut terdiri dari 10 lagu dan memiliki perubahan makna kias dengan lirik-lirik lagu yang memberikan nuansa musik beraliran Balada, Rock, Pop, dan Country. Album "Satu" mengangkat tema kritikan yang ditujukan kepada para penolak dan percintaan serta kalangan pejabat politik pemerintah. Lagu merupakan bagian dari seni yang lahir di masyarakat dan setiap lirik di dalamnya mengandung makna. Bahasa yang dipilih dalam lagu adalah bahasa yang indah dan mengandung fungsi puitis sebagai curahan pikiran, perasaan, dan pesan dari pengarang yang ingin disampaikan kepada pendengarnya.

Contoh lirik lagu yang mengandung makna asosiatif yakni makna konotatif pada lirik lagu Iwan Fals album musikal "Satu" tahun 2015.

\section{Saling berbagi, saling menyayangi Bersatu untuk hidup \\ Untuk hidup yang lebih baik}

Konteks pada lirik lagu di atas menceritakan sesama manusia harus saling memiliki rasa saling peduli, berbagi dan menyayangi satu sama lain serta mengutamakan kesetiaan atau kerukunan untuk menjalin suatu kehidupan yang lebih baik tanpa harus adanya pertengkaran. Berdasarkan pada kata "menyayangi" menunjukkan adanya jenis makna asosiatif yakni makna konotatif. Kata "menyayangi" menimbulkan nilai rasa positif. Reaksi yang ditimbulkan yakni perasaan simpati. Kata "menyayangi" mengalami pergeseran makna yaitu 'peduli', karena dilihat dari konteksnya kalimat pada kutipan lirik lagu tersebut pencipta lagu merasa lebih baik jika satu sama lain atau setiap orang saling peduli daripada pertengkaran. Sesuai dengan kenyataan yang ada di Indonesia bahwa generasigenerasi penerus bangsa sebagian besar sering membuat onar atau tawuran. Maka dari itu, pada lirik lagu tersebut ditujukan untuk para generasi bangsa Indonesia agar saling peduli kepada sesamanya. tujuan dari penelitian ini yaitu untuk mendeskripsikan jenis makna asosiatif pada lirik lagu Iwan Fals di album musikal "Satu" tahun 2015.

Penelitian ini menggunakan beberapa teori yang relevan dan diharapkan dapat mendukung temuan yang diteliti agar dapat memperkuat teori dan keakuratan data. Teori-teori tersebut adalah semantik, makna, makna asosiatif, lirik, album "Satu".

Kata semantik dalam bahasa Indonesia berasal dari bahasa Yunani sema kata benda yang berarti "tanda" atau "lambang". Kata kerjanya adalah semaino yang berarti "menandai" atau "melambangkan". Yang dimaksud dengan tanda atau lambang sebagai padanan kata sema adalah tanda linguistik seperti yang dikemukakan oleh Ferdinand de Saussure (Chaer, 2009, p. 2) yaitu yang terdiri dari (a) komponen yang mengartikan, yang berwujud bentuk-bentuk bunyi bahasa dan (b) komponen yang diartikan atau makna dari komponen yang pertama itu. Kedua komponen ini adalah merupakan alat 
tanda atau lambang; sedangkan yang ditandai atau dilambangnya adalah sesuatu yang di luar bahasa yang lazim disebut referen atau hal yang ditunjuk.

Djajasudarma (2012, p. 7) menyatakan bahwa makna adalah peraturan yang ada di dalam unsur diantara unsur-unsur bahasa itu sendiri terutama kata-kata. Makna sebagai penghubung bahasa dengan dunia luar sesuai dengan kesepakatan para pemakainya sehingga dapat saling mengerti.

Menurut Chaer (2009, p. 72) makna yang dimiliki sebuah kata berkenan dengan adanya hubungan kata itu dengan keadaan di luar bahasa. Misalnya kata melati berasosiasi dengan makna 'suci', atau 'kesucian'; kata merah berasosiasi dengan makna 'berani', atau juga 'dengan golongan komunis'; kata cendrawasih berasosiasi dengan makna 'indah'. Dengan kata lain, makna asosiatif merupakan perlambanganperlambangan yang sering digunakan di suatu masyarakat bahasa untuk menyatakan suatu konsep lain. Makna asosiatif sudah bergeser dari makna sebenarnya, namun makna asosiatif tersebut ada kaitannya dengan makna sebenarnya. Oleh karena itu, makna asosiatif memiliki hubungan dengan nilai-nilai moral dan pandangan hidup yang berlaku di dalam suatu masyarakat bahasa yang juga berhubungan dengan nilai-nilai rasa bahasa.

Jadi dapat disimpulkan bahwa makna asosiatif adalah perubahan makna kata akibat adanya persamaan sifat yang dapat dihubungkan dengan benda lain yang dianggap mempunyai kesamaan sifat, maka dapat juga dikatakan sebagai makna kias. Makna asosiatif adalah adanya hubungan dengan nilai moral dan pandangan hidup berlaku pada suatu masyarakat bahasa yang berurusan juga dengan nilai rasa bahasa.

Jenis makna asosiatif yang diterapkan oleh Leech (Chaer, 2009), yang meliputi definisi makna konotatif, makna stilistik, makna afektif, makna reflektif, dan makna kolokatif. Makna konotatif yaitu makna yang berhubungan dengan perasaan pemakai bahasa terhadap kata yang didengar atau kata yang dibaca. kata "babi" berkonotasi negatif, "kurus" berkonotasi netral, "ramping" berkonotasi positif, dan "kerempeng" berkonotasi negatif. Berkaitan dengan masalah konotasi, satu hal yang harus diingat adalah bahwa konotasi sebuah kata bisa berbeda antara seorang dengan orang lain, antara satu daerah dengan daerah lain, atau antara satu masa dengan masa yang lain.

Makna stilistik yaitu makna yang berhubungan dengan adanya perbedaan sosial dan kegiatan di dalam masyarakat. Kata "pergi" pada kalimat "Mengapa terlalu cepat kau pergi", jika dilihat dari konteks kalimatnya, maka kata pergi mempunyai makna yang sama dengan kata-kata 'mati', 'meninggal', 'mampus', 'modar', dan 'wafat' yang mempunyai arti tidak hidup lagi atau tidak bernyawa lagi.

Makna afektif berarti adanya sebuah reaksi terhadap pendengar atau pembaca. Makna afektif yang menggambarkan atau mencerminkan perasaan pribadi penutur termasuk sikapnya terhadap pendengar atau sikapnya terhadap sesuatu yang dikatakannya. Makna afektif lebih terasa secara lisan daripada secara tertulis. Pada kalimat "Tutup mulut kalian!" jika diucapkan secara langsung akan terdengar kasar bagi pendengarnya. Misalnya, seseorang yang ditegur dengan kalimat-kalimat tersebut akan menjadi santai jika intonasi suara yang digunakan dengan lembut

Makna reflektif yakni adanya pengertian kata yang memunculkan perngeritian lain dari yang direspon dan difikirkan si pendengar terhadap kata yang kita ucapkan. Makna reflektif juga merupakan makna yang muncul oleh penutur pada saat merespon apa yang dia lihat. Kata "aduh" mempunyai 
makna pantulan atau memunculkan makna lain. Kata "aduh" mempunyai makna 'menyatakan rasa heran'.

Makna kolokatif adalah adanya sebuah informasi yang sama dalam satu kolokasi. Berikut contoh kalimat makna kolokatif yang memiliki makna berbeda namun informasinya sama yaitu "Ibu membeli kebutuhan dapur seperti ikan, garam, gula, sayur, dan tomat". Pada contoh kalimat tersebut, kata (ikan, garam, gula, sayur, dan tomat) memiliki informasi lingkungan yang sama yaitu berada di lingkungan dapur.

Depdiknas (Darwati, 2017, p. 26) lirik merupakan susunan kata yang indah pada sebuah lagu atau nyanyian. Lagu yang terbentuk dari hubungan antara unsur musik dengan unsur syair atau lirik lagu merupakan salah satu bentuk komunikasi massa. Dari penjelasan di atas dapat disimpulkan bahwa lirik lagu merupakan ekspresi seseorang tentang suatu hal yang sudah dilihat, didengar maupun yang telah dialaminya. Dalam mengungkapkan pengalamannya, penyair atau pencipta lagu melakukan permainan kata-kata dan bahasa untuk menciptakan daya tarik dan ciri khas terhadap lirik atau syairnya.

Musisi Iwan Fals, memiliki album terakhir yaitu "Satu" yang dirilis tahun 2015 yang berkaloborasi bersama musisi ternama di Indonesia dan musik dalam album ini bergenre pop dan alternatif. Album "Satu" ini rilis dibawah label yang telah membesarkan nama Iwan Fals, Musica Studio's yang didirikan tahun 1968 oleh Yamin Widjaja. Album "Satu" merupakan album ketiga puluh tiga yang dirilis oleh Iwan Fals, meskipun sudah memiliki banyak album namun album "Satu" ini banyak disukai oleh kalangan masyarakat. Kehadiran Iwan Fals dalam album "Satu" ini memberikan nuansa musik yang baru dan tema yang diangkat dalam albumnya ini mengkritik para penolak dan percintaan serta kalangan pejabat pemerintahan.
Dalam album "Satu" ini menghadirkan sepuluh lagu yang terdiri dari: 2 lagu kompilasi, 4 lagu terbaik Iwan Fals yang diaransemen dan dinyanyikan ulang dengan konsep fullband, dan 4 lagu baru dari masingmasing artis yang terlibat dalam album ini. Adapun judul lagu pada album Satu tersebut, yaitu: Abadi, Tak Seimbang, Yang Terlupakan, Satu-Satunya, Hidup Yang Hebat, Entah, Para Penerka, Ijinkan Aku Menyayangimu, Pesawat Tempurku, Kemesraan.

Penelitian pada analisis makna pada lagu tentu saja sudah ada yang meneliti pada waktu sebelumnya, namun penelitian sebelumnya menggunakan objek dan fokus penelitian yang berbeda dengan penelitian yang diambil oleh peneliti. Pada penelitian ini peneliti mengambil judul Pergeseran Makna Asosiatif Pada Lirik Lagu Iwan Fals Album Musikal "Satu" Tahun 2015 sebagai kajiannya. Sedangkan penelitian sebelumnya oleh Astutik (2015) membahas tentang Makna Asosiatif Dalam Lirik Lagu Tommy J Pisa, Widijayanto (2015) Makna Konseptual dan Makna Asosiatif Dalam Teks Lagu Sheila On 7, dan Kasopa (2017) dengan judul Makna Asosiatif Dalam Kitab Mazmur.

\section{METODE PENELITIAN}

Dalam penelitian ini pendekatan yang dilakukan adalah melalui pendekatan semantik. Semantik sebagai ilmu yang mengkaji tentang makna atau tentang arti. Jenis penelitian ini menggunakan jenis penelitian kualitatif. Menurut Moleong (2017, p. 6) yang dimaksud dengan penelitian kualitatif adalah penelitian yang bermaksud untuk memahami fenomena tentang apa yang dialami oleh subjek penelitian misalnya perilaku, persepsi, motivasi, tindakan, dan lain-lain. Jenis penelitian ini mengacu pada penelitian deskriptif, yaitu penelitian yang berupa penggambaran tentang suatu keadaan tertentu. Dalam 
hal ini, peneliti mendeskripsikan secara sistematis, teliti, rinci, faktual, dan akurat mengenai fakta-fakta dan hubungan kausal fenomena yang diteliti.

Menurut Moleong (2017, p. 157) data penelitian kualitatif jenis datanya dibagi ke dalam kata-kata dan tindakan, sumber data tertulis, foto, dan statistik. Data yang dikumpulkan dalam penelitian ini meliputi berupa kata dan frasa pada lirik lagu Iwan Fals di album musical "satu" yang mengandung makna asosiatif. Menurut Arikunto (2013, p. 172) sumber data adalah subjek dari mana data dapat diperoleh. Pada penelitian ini peneliti mengambil sumber data pada lirik lagu Iwan Fals yang terdapat pada album musikal "satu" tahun 2015 yang berjumlah 10 lagu yang berjudul Abadi, Tak Seimbang, Yang Terlupakan, Satu- Satunya, Hidup Yang Hebat, Entah, Para Penerka, Ijinkan Aku Menyayangimu, Pesawat Tempurku dan Kemesraan.

Teknik pengumpulan data dalam penelitian ini menggunakan dua metode yaitu teknik simak dan teknik catat sebagai teknik lanjutan.

1) Metode simak adalah metode yang digunakan untuk memperoleh data dengan menyimak penggunaan bahasa. Seperti yang dikatakan Mahsun (Muhammad, 2014, p. 217) metode teknik simak adalah metode yang digunakan untuk memperoleh data dengan melakukan penyimakan terhadap penggunaan bahasa. Teknik simak dalam penelitian ini yaitu peneliti hanya berperan sebagai pengamat penggunaan bahasa dan sama sekali tidak terlibat langsung.

2) Teknik catat adalah mencatat beberapa bentuk yang relevan bagi peneliti dari penggunaan bahasa secara tertulis. Menurut Mahsun (Muhammad, 2014, p. 218) metode teknik catat adalah teknik lanjutan yang dilakukan ketika menerapkan metode simak. Metode teknik catat digunakan sebagai teknik dalam pengumpulan data. Pada penelitian ini penulis memperoleh informasi dari hasil analisis data yang berupa lirik lagu Iwan Fals di album "Satu" yang telah dikumpulkan sebagai sumber bahan penelitian, kemudian data yang telah diperoleh tersebut dicatat untuk dipelajari dan dianalisis sesuai dengan kebutuhan dalam penelitian ini.

Dalam penelitian deskriptif kualitatif ini yang menjadi instrumen utama penelitian ini adalah peneliti sendiri yang bertindak sebagai pembaca aktif bertugas mencari data- data dengan cara membaca keseluruhan sumber data dan dibantu dengan alat instrumen berupa kartu data berupa kertas, pensil 2B sebagai alat tulis, perangkat alat elektronik berupa laptop merk Asus X453S dan kaset CD original.

Kartu data digunakan untuk mencatat seluruh data yang telah diperoleh. Data-data berupa kata-kata yang mengandung makna asosiatif yang meliputi makna konotatif, makna stilistik, makna afektif, makna reflektif, dan makna kolokatif kemudian dicatat dalam kartu data menggunakan alat tulis.

Pemeriksaan keabsahan data didasakan atas kriteria tertentu. Penerapan kriteria derajat kepercayaan ini berfungsi melaksanakan inkuiri sedemikian rupa sehingga tingkat kepercayaan penemuannya dapat dicapai dan dapat mempertunjukkan derajat kepercayaan hasil-hasil penemuan dengan jalan-jalan pembuktian oleh peneliti. Adapun tentang teknik tersebut dijelaskan oleh Moleong (2017:329334), yaitu sebagai berikut :

1) Ketekunan Pengamatan, ketekunan pengamatan bermaksud menemukan ciri-ciri dan unsur-unsur dalam situasi yang sangat relevan dengan persoalan atau isu yang sedang dicari kemudian memusatkan diri pada hal-hal tersebut secara rinci. Teknik yang dilakukan adalah mengamati lirik lagu Iwan Fals di album musikal "Satu" tahun 2015 secara sistematis, teliti, rinci, factual, dan akurat terhadap berbagai 
fenomena yang berhubungan dengan masalah dan data penelitian.

2) Triangulasi, triangulasi yang digunakan peneliti ialah teknik pemeriksaan menggunakan penyidik. Teknik triangulasi penyidik ialah dengan jalan memanfaatkan peneliti atau pengamat lain untuk keperluan pengecekan kembali derajat kepercayaan data. Adanya pengamat dalam penelitian ini, tentunya akan membantu peneliti mengurangi penyimpangan dalam pengumpulan data pada lirik lagu Iwan Fals di album musikal "Satu" tahun 2015.

Analisis data dalam penelitian ini adalah analisis deskriptif kualitatif. Sebagaimana yang dikemukakan oleh Miles dan Huberman (Sugiyono, 2015, p. 337) bahwa aktivitas dalam analisis data kualitatif dilakukan secara interaktif dan berlangsng secara terus-menerus sampai tuntas. Dibawah ini akan dijelaskan komponen dalam analisis tersebut yaitu:

1) Reduksi Data

Data yang diperoleh jumlahnya cukup banyak, untuk itu perlu dicatat secara teliti dan rinci. Mereduksi data berarti merangkum, memilih hal-hal pokok, memfokuskan pada hal-hal yang penting. Data dalam penelitian ini adalah lirik lagu Iwan Fals di album musikal "Satu" tahun 2015.

2) Penyajian Data

Setelah data direduksi, maka langkah selanjutnya adalah menyajikan data dalam penelitian kualitatif bisa dilakukan dalam bentuk uraian singkat, bagan, hubungan antar kategori, dan sejenisnya. Penyajian data dilakukan bertujuan untuk memahami apa yang terjadi dan merancang kerja selanjutnya berdasarkan apa yang telah dipahami. Dalam hal penyajian data dalam penelitian ini peneliti melakukan pencatatan data yang berupa larik pada lirik lagu Iwan Fals di album musikal "Satu" tahun 2015.
3) Penyimpulan data

Pada tahap ini hasil analisis dapat diambil kesimpulan secara umum. Kesimpulan ini merupakan tahapan yang terakhir dalam penelitian agar lebih mudah dan memperjelas dalam memaparkan penelitian pergeseran makna asosiatif pada lirik lagu Iwan Fals di album musikal "Satu” tahun 2015.

\section{HASIL DAN PEMBAHASAN}

Pada hasil dan pembahasan penelitian ini, akan dipaparkan hasil dan pembahasan penelitian yang telah diteliti yaitu pergeseran makna asosiatif pada lirik lagu Iwan Fals di album musikal "Satu" tahun 2015. Dalam lirik lagu tersebut ditemukan 5 jenis komponen makna dari 33 data. Jenis makna asosiatif dikelompokkan menjadi lima komponen makna, yaitu (1) makna konotatif, (2) makna stilistik, (3) makna afektif, (4) makna reflektif, (5) makna kolokatif.

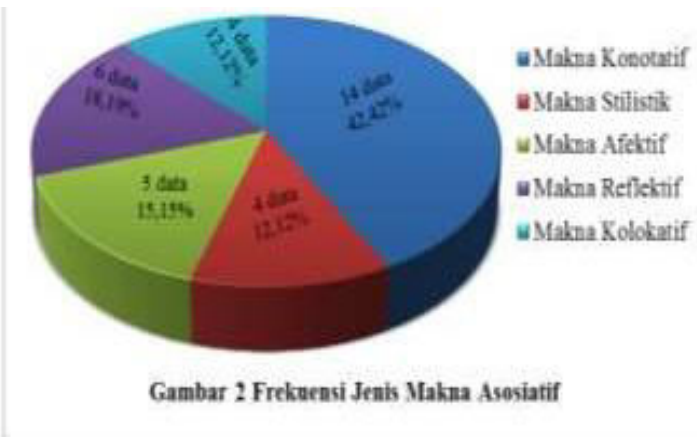

A. Wujud Makna Konotatif Pada Lirik Lagu Iwan Fals Album Musikal "Satu" Tahun 2015.

Data (1)

Pendengki bengong diterkam rindu. Apa jadinya bila semua saling mencela, saling mencela (PP/MKN/6/1) (Para Penerka)

Pada data (1) tersebut menunjukkan bahwa kata "diterkam" pada kutipan lirik lagu tersebut tergolong dalam jenis makna asosiatif yakni makna konotatif. Kata "diterkam" menimbulkan nilai rasa negatif. Reaksi yang ditimbulkan yakni 
perasaan benci. Kata "diterkam" mengalami pergeseran makna. Menurut KBBI sendiri kata "diterkam" secara umum yaitu menubrukee, menangkapee, dan menerpa ${ }^{\text {ee}}$. Berdasarkan konteks data tersebut, kata "diterkam" mengalami pergeseran makna menjadi, dibayangie dan diganggue, dan mengusikee. Arti kata "diterkam" bila dipahami secara mendalam sesuai dengan konteks kalimat dalam lirik lagu "Para Penerka" tersebut yakni para haters atau para penolak yang dibayangi rindu perasaan benci untuk saling mencela satu sama lainnya.

\section{B.Wujud Makna Stilistik Pada Lirik Lagu Iwan Fals Album Musikal "Satu" Tahun 2015.}

Data (2)

Hei...kau yang manis singgalah dan ikut bernyanyi

Sebentar saja nona, sebentar saja hanya sebentar

Rayuan mautku tak membuat kau jadi galak

Bagai seorang diplomat ulung engkau mengelak

(PT/MST/2/2) (Pesawat Tempurku)

Pada data (2) menunjukkan bahwa kata "nona" dalam kutipan lirik lagu "Pesawat Tempurku" tergolong jenis makna asosiatif yakni makna stilistik. Kata "nona" mengalami pergeseran makna. Kata "nona" pada kutipan data tersebut bersinonim dengan kata-kata "dara"e, "gadis"e, dan "noniee. Namun, masing- masing memperlihatkan perbedaan secara stilistik pada gaya bahasanya. Kata "dara" dipakai secara umum untuk penyebutan anak perawan yang belum kawin"e. Kata "gadise dipakai secara umum untuk sebutan „,anak perempuan yang sudah akil baligee. Kata "nonie dipakai secara umum untuk sebutan „nona kecil"e. Sesuai dengan kenyataan data (2) pada KBBI kata "nona" biasanya dipergunakan untuk menyatakan kegiatan yaitu sebutan bagi anak perempuan atau wanita yang belum menikah, namun kata "nona" pada lirik lagu "Pesawat Tempurku" menyatakan sebuah situasi terjadinya ucapan. Sesuai dengan konteks tersebut kata "nona" di zamannya merupakan penyebutan untuk kalangan bangsawan.

\section{Wujud Makna Afektif Pada Lirik Lagu Iwan Fals Album Musikal "Satu" Tahun 2015.}

Data (3)

Yaya yaya yaya jangan cuma yayaya aje Haha Gile loe. Siape yang gile oom... Bule gile Lilly

(HYH/MAF/4/2) (Hidup Yang Hebat) Kutipan data (3) menunjukkan bahwa kata yang dicetak tebal dalam lirik lagu "Hidup Yang Hebat" tergolong jenis makna asosiatif yakni makna afektif. Kata "Gile loe" merupakan kata kasar yang mengandung makna yang berhubungan dengan rasa penghinaan. Kata "Gile loe" mengalami pergeseran makna, sehingga memiliki makna ,gila kamue, karena dilihat dari konteks kalimatnya, kutipan lirik lagu tersebut pencipta lagu menyebutkan bahwa gila kamu ditujukan kepada Bule Lilly atau para haters dan para penolak.

\section{Wujud Makna Reflektif Pada Lirik Lagu Iwan Fals Album Musikal "Satu" Tahun 2015.}

Data (4)

Ooohh Habislah kita

(AB/MRF/4/1) (Abadi)

Analisis data (4) tersebut menunjukkan bahwa kata "Ooohh" pada kutipan lirik lagu tersebut tergolong jenis makna asosiatif yakni makna reflektif. Dalam KBBI kata "Ooohh" mengalami pergeseran makna dan memantulkan makna lain yaitu „kecewa ${ }^{\text {ee }}$, „haru ${ }^{\text {ee }}$, dan „yakin“. Oleh karena itu, pada data (4) lirik lagu tersebut ditujukan untuk para generasi bangsa Indonesia bahwa sang pencipta lagu merasa kecewa kepada generasi penerus bangsa yang saling tawuran tanpa mempedulikan yang lain. 


\section{E. Wujud Makna Makna Kolokatif Pada Lirik Lagu Iwan Fals Album Musikal "Satu" Tahun 2015.}

Data (5)

Denting piano kala jari jemari menari

Nada merambat pelan di kesunyian malam

Saat datang rintik hujan bersama sebuah bayang

Yang pernah terlupakan

(YT/MKL/1/2)(Yang Terlupakan)

Berdasarkan data (5) kata "kesunyian malam" dalam kutipan data menunjukkan adanya jenis makna asosiatif yakni makna kolokatif. Kata "kesunyian malam" tersebut mengalami pergeseran makna dan muncul dalam lingkungan yang sama. Kata "kesunyian malam" dalam kutipan lirik lagu tersebut termasuk makna kolokatif, karena makna kata "kesunyian malam" tersebut dalam KBBI mengalami pergeseran makna dan mempunyai kolokasi dengan kata-kata, keheningan ${ }^{e e}$ kesenyapan ${ }^{\text {ee, }}$ kelenggangan $^{\text {ee dan kesepian }}{ }^{\text {ee }}$. Dilihat dari konteks kalimat pada kutipan lirik lagu tersebut pencipta lagu menceritakan keadaan seseorang yang merasakan kesepian saat kegelapan mulai datang.

\section{F. Hasil Penemuan Kata Yang Termasuk Dalam Tiga Jenis Makna}

Dari hasil analisis data, ditemukan adanya data yang sama masuk ke dalam tiga jenis makna yaitu makna konotatif, makna stilistik dan makna afektif. Data tersebut merupakan kata ,gile ${ }^{e e}$ dan „loee . Namun masingmasing memiliki perbedaan diantara jenis makna tersebut. Pada makna konotatif, kata ,gile dan „loe menimbulkan nilai rasa negatif. Pada makna stilistik, kata ,gile dan „loe merupakan dialek yang dipakai pada bahasa daerah atau lingkungan tertentu yang merupakan kata serapan dari bahasa betawi. Sedangkan pada makna afektif, kata "gila loe ee merupakan kata kasar yang mengandung makna yang berhubungan dengan rasa penghinaan.

\section{KESIMPULAN}

Berdasarkan hasil analisis yang berjudul "Pergeseran Makna Asosiatif Pada Lirik Lagu Iwan Fals Di Album Musikal "Satu" Tahun 2015", dapat disimpulkan bahwa makna asosiatif yang ditemukan dalam penelitian ini meliputi 5 jenis komponen makna, yaitu (1) makna konotatif, (2) makna stilistik, (3) makna afektif, (4) makna reflektif, (5) makna kolokatif.

Makna asosiatif yang terdapat dalam lirik lagu Iwan Fals di album musikal "Satu" tahun 2015 diperoleh sebanyak 33 data dari hasil penelitian. Tetapi jenis makna asosiatif yang paling dominan atau sering digunakan yaitu makna konotatif, ditemukan sebanyak 14 data dengan frekuensi $42,42 \%$. Data-data yang diperoleh adalah diterkam, menyayangi, omong kosong, menghitam hati, menggonggong, hangatkan jiwa, loe, gile, lari dari kenyataan, sinar surya, tenggelam, berjalan tanpa kamu, lemparkan senyum, dan provokasi. Makna konotatif yang menjadi paling dominan, karena pada penggunaan bahasa banyak menggunakan kata-kata kiasan yang diggunakan untuk penyampaian makna, agar penyair atau penyanyi tidak menyinggung secara langsung terhadap para pendengarnya.

Sedangkan jenis makna yang paling jarang digunakan yaitu jenis makna stilistik dan makna kolokatif, sebab ditemukan 4 data saja atau frekunsi penggunaannya hanya $12,12 \%$. Makna stilistik dan kolkatif yang paling jarang digunakan, karena pada makna stilistik jarang menggunakan kata-kata yang mengandung makna sosial dalam pemakaian dialek dan ragam tulis maupun ragam lisan. Data-data yang diperoleh pada makna stilistik yaitu nona, loe, gile dan segaye. Sedangkan pada makna kolokatif jarang menggunakan kata-kata yang 
mempunyai informasi yang sama dalam satu kolokasi. Sebab, jarang adanya katakata yang terikat dengan kata-kata tertentu dalam satu frase. Data-data yang diperoleh pada makna kolokatif yaitu terisak-isak, tangisku, tawa riangmu, dan kesunyian malam.

\section{DAFTAR PUSTAKA}

Arikunto, S. (2013). Prosedur Penelitian Suatu Pendekatan Praktik. Jakarta: Rineka Cipta.

Astutik, Y. (2015). Makna Asosiatif Dalam Lirik Lagu Tommy J Pisa: Pendidikan Bahasa dan sastra Indonesia. Universitas PGRI Jombang, vol 1, nol 2017, hal 4.

Chaer, A. (2009). Pengantar Semantik Bahasa Indonesia. Jakarta: Rineka Cipta.

Daring. (2016). Retrieved from Kamus Besar Bahada Indonesia: Badan Pengembangan dan Pembinaan Bahasa Indonesia. Tersedia online di Http://kbbi.kemendikbud.go.id/ diakses pada 3 Maret 2018.

Darwati, N. D. (2017). Analisis Makna Asosiatif Pada Lirik Lagu Muhammad Tulus Rusyidi dalam Album Tulus Gajah dan Monokrom. Universitas Muhammadiyah Malang, hal 26.

Djajasudarma, F. (2012). Semantik 1 Makna Leksikal dan Gramatikal. Bandung: Remaja Rosdakarya.

Kasopa, J. K. (2017). Makna Asosiatif Dalam Kitab Mazmur: Fakultas Ilmu Budaya. Universitas Sam Ratulangi, vol 2 no 3, hal 1.

Moleong, L. (2017). Metodologi Penelitian Kualitatif. Bandung: $\mathrm{Pt}$ Remaja Rosdakarya.

Muhammad. (2014). Metode Penelitian Bahasa. Jogjakarta: Ar-Ruzz Media.

Sugiyono. (2015). Metode Penelitian Pendidikan. Bandung: Alfabeta.

Widijayanto, A. (2015). Makna Konseptual dan Makna Asosiatif Dalam Lirik Lagu Sheila On 7: Fakultas Bahasa dan Seni.
Universiatas Negeri Semarang, vol 4 no 1 , hal 1. 